\title{
PRINCIPAL AGENT DALAM INDUSTRI PERIKANAN TANGKAP; KONTRAK YANG MENGUATKAN ATAU MELEMAHKAN? (STUDI KASUS PERIKANAN TANGKAP DI PESISIR MALANG SELATAN)
}

\section{Principal Agent in the Commercial Fishing Business; Strengthening or Weakening Contracts? (Case Study of Commercial Fishing Business in the Coastal of South Malang)}

\author{
*Yenny Kornitasari', Asfi Manzilati', dan Anthon Efani \\ ${ }^{1}$ Fakultas Ekonomi dan Bisnis, Universitas Brawijaya \\ Jalan MT. Haryono 165, Malang 65145; Phone. (0341) 551396, 555 000, Indonesia \\ ${ }^{2}$ Fakultas Perikanan dan IImu Kelautan, Universitas Brawijaya \\ Jalan Veteran, Malang; Phone. (0341) 553512 Fax. 0341 557837, Indonesia \\ Diterima tanggal: 19 Desember 2018 Diterima setelah perbaikan: 28 Juni 2019 \\ Disetujui terbit: 10 Desember 2019
}

\begin{abstract}
ABSTRAK
Penelitian ini bertujuan untuk mengidentifikasi secara detail bagaimana hubungan kerja/ industrial (principal-agent) dalam menjaga keberlanjutan suatu usaha di sektor perikanan. Penelitian ini menggunakan pendekatan kualitatif untuk melihat realitas yang tidak hanya dilihat sebagai sebuah hasil, tetapi juga proses yang berlangsung. Proses observasi dan intreprestasi menggunakan metode blumer. Hasil penelitian menunjukan bahwa sumber modal sebagai pembiayaan dalam operasional sektor perikanan di pesisir Malang Selatan secara umum berasal dari tiga sumber yaitu bank, aset pribadi dan-pengambek. Modal yang berasal dari bank hanya bisa diakses oleh nasabah yang memiliki agunan seperti sertifikat rumah/tanah dan kendaraan bermotor. Pedagang kecil yang tidak memiliki asset untuk dijadikan agunan lebih memilih permodalan yang berasal dari koperasi, bank thitil dan pengambek. Sumber pemodalan yang berasal dari bank, koperasi maupun bank thitil sudah jelas kontrak yang terbangun. Yang unik pada kasus ini adalah sistem permodalan yang dilakukan antara nelayan dengan pengambek. Dalam hal ini, kontrak yang terbentuk antara principal dan agent disini seperti menguntungkan kedua belah pihak, akan tetapi dalam kenyataannya nelayan tidak punya kekuatan dan pilihan lain dalam mengembangkan usaha karena terikat dengan kontrak pemodalan dan juga utang yang tidak boleh dilunasi.
\end{abstract}

Kata Kunci: principal - agent; kontrak bisnis; masyarakat pesisir

\section{ABSTRACT}

The study aims to identify in detail how work / industrial relationship (principal-agent) in maintaining the sustainability of fisheries business. This study used a qualitative approach to perceive reality as a result as well as an ongoing process. The Blumer method was used for the observation and interpretation of the data. As financial support of fisheries sector in the coast of South Malang, capital generally comes from three sources: banks, personal assets and scavengers. Bank capital can only be accessed by customers having collateral asset such as house, land, or vehicles certificates. While cooperative, thitil bank and pengambek were the capital sources for the small traders who do not have collateral assets. It is clear that there is a contract system for acquiring bank and cooperative capital. The unique case appears from capital system between fishers and "pengambek". The system seemed to have a mutual advantageous for both party, however, fishers have less power and choice to get alternative source of capital in developing their business due to the restriction of their contract and they are not allowed to settle their debt.

Keywords: principal - agent; business contract; coastal community 


\section{PENDAHULUAN}

Sebagai negara kepulauan, Indonesia memiliki garis pantai terpanjang di kawasan Asia Tenggara. Menurut Badan Informasi Geospasial (BIG) panjang garis pantai Indonesia mencapai $99.093 \mathrm{~km}^{2}$. Dengan demikian, tidaklah berlebihan jika mengatakan Indonesia memiliki keunggulan pada bidang kelautan dan pesisirnya (Satria, 2002). Kurniasari \& Reswati (2011:7) kondisi tersebut memberikan konsekuensi potensi ikan yang terdapat pada laut Indonesia mencapai 6,26 Juta ton per tahun. Kekayaan sumber daya laut ini menjadi anugerah tersendiri bagi sekitar 60 persen dari total penduduk masyarakat Indonesia tercatat mendiami daerah pesisir ini (Wahyudin, 2015:1).

Potensi sumber daya tersebut seolah berbanding terbalik dengan kesejahteraan masyarakat pesisir. Hal ini dapat dilihat dari data statistik tahun 2015, dari jumlah populasi penduduk miskin di Indonesia sebesar 25\% atau sekitar 7,7 juta jiwa berasal dari nelayan. Hal ini mengindikasikan keadaan sosial ekonomi masyarakat yang berada pada daerah pesisir masih rendah. Menurut Masyhuri (1999) hal tersebut didiorong dari penyelesaian permasalahan yang bersifat parsial dan tidak menyeluruh sering kali dianggap sebagai tantangan dalam permasalahan pengentasan kemiskinan pada masyarakat pesisir khususnya nelayan.

Kurniasari dan Reswati (2011:8) menjelaskan salah satu penebab nelayan sulit keluar dari situasi yang dialaminya adalah masalah ketergantungan nelayan yang cukup besar pada faktor produksi khususnya permasalahan permodalan kepada pemilik modal. Sehingga untuk mengatasi permasalahan tersebut seringkali nelayan melakukan kontrak atau kerjasama dengan pihak lain sehingga terbentuklah principal dan agent dalam industri perikanan tangkap.

Berdasarkan hal tersebut, penelitian ini hendak menelusuri bagaimana kontrak yang terjadi pada tatanan sosial masyarakat nelayan pesisir Malang Selatan. Sebagaimana disebutkan oleh Kurniasari dan Reswati (2011:8) salah satu permasalahan kemiskinan masyarakat nelayan pesisir adalah ketergantungan pada pemilik modal, pada gilirannya akan membentuk pola kerjasama yang tidak setara diantara pelaku ekonomi pesisir. Melalui penelitian ini diharapkan mampu berkontribusi dalam penyempurnaan programprogram yang telah dilaksanakan sebelumnya khususnya pada program pembiayaan dan permodalan bagi nelayan.

Secara literal, kontrak adalah kesepakatan atau perjanjian yang dilakukan oleh 2 pihak atau lebih untuk melakukan suatu kegiatan seperti berdagang atau sewa menyewa (KBBI, 2010). Menurut Yustika (2012) kontrak secara umum digambarkan sebagai kesepakatan satu pelaku untuk melakukan tindakan yang memiliki nilai ekonomi kepada pihak lain, tentunya ada konsekuensi seperti tindakan balasan atau pembayaran yang mengikutinya. Dari definisi tersebut maka kontrak merupakan elemen yang mengatur atau mengarahkan suatu kegiatan yang dilakukan oleh beberapa pihak dengan tujuan tertentu. Selain itu, kegiatan yang diatur dalam kontrak dapat beragam namun pada umumnya kontrak muncul pada kegiatan yang melibatkan 2 atau lebih tujuan (interest) individu dalam suatu kegiatan sehingga memungkinkan terjadinya conflict of interest.

Kontrak dalam kondisi assymetric information muncul sebagai mekanisme penegakan untuk mempertahankan posisi antar aktor agar tidak ada penyimpangan dari kesepakatan awal. Artinya kontrak dapat mengurangi assymetric information kemudian mengurangi biaya transaksi yang ada dalam sebuah kegiatan. Secara teknis, informasi asimetris tidak lain merupakan kondisi di mana keridaksetaraan informasi atau pengetahuan (unequal knowledge) yang dialami oleh pelakupelaku (parties) untuk melakukan transaksi di pasar (Yustika, 2012). Di sinilah dibutuhkan suatu kontrak yang lengkap sehingga eksistensi informasi asimetris tadi dapat dikurangi atau direduksi.

Jika teori kontrak berdasarkan Yustika (2012) diterapkan dalam konteks fenomena penelitian, maka kesepakatan yang terjadi antar aktor ekonomi adalah kesepakatan antara nelayan dan pengambek. Sebagai aktor ekonomi, mereka diasumsikan rasional dan self - maximizing interest. Sehingga dengan cara - cara yang rasional menurut tiap aktor, mereka akan mencari kepuasan maksimum walaupun cara tersebut dapat menciderai kontrak yang telah didesain sebelumnya. Hal ini sesuai dengan pembagian jenis kontrak yang dilakukan oleh Furubotn \& Richter (dalam Yustika, 2012) dimana assymetric information dapat terjadi antara pemilik sebagai principal dan pegawai sebagai agen yang keduanya memiliki tujuan yang berbeda. Oleh kerena itu bagian selanjutnya dalam bahasan ini akan menjelaskan mengenai teori principal agent untuk menjelaskan bagaimana teori kontrak 
eksis dalam hubungan yang terjadi nelayan dan pengampek.

Selanjutnya, Principal-Agent Theorymemiliki akar masalah pada conflict of interest antar aktor. Dalam hal ini prinsipal adalah aktor yang memiliki kepentingan dan memberikan tugas pada agen untuk menjalankan kepentingan tersebut. Dalam interaksi antar aktor tersebut, walaupun pemangku kepentingan dalam suatu kegiatan adalah prinsipal namun agen memiliki informasi yang lebih lengkap. Kelengkapan informasi agen disebabkan karena posisi mereka yang melaksanakan kepentingan prinsipal secara langsung.

\section{METODOLOGI}

\section{Pendekatan Penelitian}

Penelitian ini menggunakan pendekatan kualitatif, pendekatan kualitatif dipilih karena dapat digunakan untuk melihat realitas, dalam hal ini tidak sekedar sebuah hasil, tetapi bagaimana proses berlangsung dan realitas-realitas lain yang melingkupi proses itu. Pendekatan kualitatif pada dasarnya sangat tekun dalam posisi filosofis, dimana kebanyakan imterpretivis memberiperhatian kepada bagaimana dunia sosial diinterpretasi, dimengerti, dialami atau dihasilkan dalam sebuah proses (Mason1996:4).

\section{Lokasi dan Waktu Penelitian}

Penelitian ini dilaksanakan di Pantai Sendangbiru Desa Tambakrejo, Kecamatan Sumbermanjing Wetan, Kabupaten Malang. Waktu penelitian dimulai pada tahun 2017 hingga Januari 2019.

\section{Jenis dan Metode Pengambilan Data}

Sejalan dengan pendekatan kualitatif, jenis datayang diambil sebagai bahan untuk menganalisis perubahan posisi principal-agent adalah jenis data primer yang diambil dari beberapa sumber informan utama dan informan pendukung sebagai sumber data. Adapun informan utama adalah pelaku ekonomi pesisir yang melakukan interaksi principal agent yaitu nelayan, pengurus kapal/pengambek, pedagang ikan, supplier logistik dan BBM, serta kuli bongkar. Selanjutnya informan pendukung adalah akademisi dan pemerintah. Adapun karakteristik dari informan tersebut yaitu mereka yang minimal 5 tahun bekerja di bidang tersebut. Selain itu juga, peneliti melibatkan diri dalam kegiatan keseharian yang dilakukan informan (masyarakat pesisir).
Sugiyono (2012) secara spesifik data yang diambil adalah data emik (tampak dalam dari manusia, persepsi, mindset, sikap, kepercayaan) dan kalaupun ada data sensual (data skunder/ kuantitatif yaitu yang dapat disensor) adalah data pendukung. Data pada penelitian ini dikumpulkan dengan menggunakan dua metode (Moleong, 2006) yaitu: Pertama, wawancara tidak terstruktur (tidak menggunakan kueisener). Kedua, observasi di lapangan yang dilakukan dengan mencoba menempatkan peneliti pada posisi pihak terteliti dan melibatkan diri (berpartisipasi) pada aktifitas uaha perikanan.

\section{Metode Analisis}

Mendasarkan pada permasalahan yang ingin dijawab, maka metode analisis dilakukan secara holistik dengan mendiskusikan hasil penelitian secara interdisiplin antara ekonomi dan ilmu sosial lainnya (Koentjaraningrat, 1990). Hal ini menjadi pilihan metode analisis dikarenakan kompleksnya struktur beragam pada komunitas pasar dan untuk menampilkan visi yang komprehensif masyarakat ekonomi di masa mendatang. Penelitian ini menggunakan pendekatan Kualitatif Interaksionisme Simbolik yang merupakan perspektif yang bertujuan untuk memahami sifat interaksi dalam masyarakat dalam aktifitas sosial secara dinamis terjadi di antara individu-individu (Charon, 1979: 23). Dengan demikian, dalam interaksi individu-individu biasa mengalami perubahan, bertindak satu sama lain, saling mempertimbangkan, bertindak, berpersepsi, menginterpretasi, dan kemudian bereaksi. Individu dalam hal ini adalah "diri" merupakan sentral bagi perspektif Interaksionisme Simbolik. Pendekatan tersebut dipilih sesuai dengan tujuan penelitian yang lebih menekankan pada pemaknaan dan proses.

Unit analisis pada penelitian ini adalah principal agent yang ada pada bisnis masyarakat pesisir dan juga beberapa pihak yang terlibat dalam proses yang terjadi di sektor perikanan diantaranya pengambek dan nelayan. Selanjutnya, proses pengambilan data pada penelitian ini dilakukan melalui survey langusung, wawancara dan juga observasi. Interpretasi data dilakukan dengan mendasarkan kepada 3 premis Blumer (1969) yaitu:

1. Manusia bertindak terhadap sesuatu berdasarkan makna-makna yang ada pada sesuatu itu bagi mereka. 
2. Makna tersebut berasal dari "interaksi" sosial seseorang dengan orang lain.

3. Makna-makna tersebut disempurnakan di saat proses interaksi sosial berlangsung.

\section{HASIL DAN PEMBAHASAN}

Secara umum, pelaku usaha perikanan di Pantai Sendang Biru terdiri atas lima kelompok, yaitu nelayan, pengurus kapal/pengambek, pedagang ikan, supplier logistik dan BBM, serta kuli bongkar, dimana kelima kelompok tersebut memiliki keterkaitan satu sama lain dalam aktivitas perikanan di Pantai Sendang Biru yang selanjutnya membentuk hubungan principal - agent antar pelaku ekonomi di sektor perikanan tersebut.

Nelayan sendiri terbagi dalam dua kelompok yaitu juragan (pemilik kapal), dan ABK (Anak Buah Kapal). Selanjutnya, pedagang juga terbagi dalam empat kelompok yaitu: (1) pedagang besar yakni pedagang yang terdaftar sebagai anggota sekaligus pedagang di KUD; (2) pedagang kecil yakni pedagang yang mendapatkan ikan langsung dari nelayan, di mana ikan tersebut adalah ikan jatah lauk (upah) ABK kadang - kadang dalam kondisi buruk; (3) pedagang pengecer yakni pedagang yang biasanya membeli ikan dari pedagang besar setelah selesai di lelang; (4) distributor lokal yakni pedagang yang membeli ikan dari pedagang besar setelah kegiatan lelang atau dari pedagang kecil untuk didistribusikan di luar wilayah Pantai Sendang Biru.

\section{Kontrak yang Tak Tertulis Namun Mengikat}

Kontrak secara umum menggambarkan kesepakatan satu pelaku untuk melakukan tindakan yang memiliki nilai ekonomi kepada pihak lain, tentunya dengan konsekuensi adanya tindakan balasan (reciprocal action) atau pembayaran sebagai kompensasi. Dalam kenyataannya (Klein, 1980:356-358; dalam yustika, 2008:105), Kállay (2012) menyebutkan bahwa masalah yang menyebabkan perlu adanya kontrak antara lain adalah kondisi ketersediaan informasi, bounded rationality, opportunism, dan asset specificity. Kondisi lapang menunjukan bahwa kontrak hubungan kerja yang terjadi antar pelaku dalam industri perikanan tersebut bersifat informal atau tidak tertulis secara baku berdasarkan pada asas kepercayaan. Dimana kepercayaan sebagai bagian dari modal non ekonomi yang cukup signifikan dan sudah berkembang di masyarakat yang sudah membudaya sebagai bagian dari aktifitas sosial dan juga ekononomi (Manzilati, 2010).

Asas kepercayaan antar pelaku ekonomi di Pantai Sendang Biru tersebut tidak serta merta muncul tanpa adanya ikatan kontrak yang mengikat di antara mereka. Adanya ketergantungan antar masyarakat di Pantai Sendang Biru berkaitan dengan hutang - piutang yang menyebabkan ikatan kontrak secara tak langsung muncul antar pelaku usaha sektor perikanan di Pantai Sendang Biru. Adanya hutang - piutang secara langsung mengikat seseorang untuk terus memiliki hubungan kerja dengan kreditor yang telah memberi pinjaman tersebut. Jika sesorang ingin berhenti atau memutus hubungan kerja dengan pihak yang telah memberi pinjaman, maka pihak yang berhutang harus dapat melunasi hutangnya terlebih dahulu.

Berikut merupakan kutipan pernyataan salah satu informan yang bekerja sebagai Anak Buah Kapal (ABK) di Pantai Sendang Biru:

\section{“...ya langsung misalnya kasih pinjaman sekarang gak boleh kerja di orang lain, kan saya kan punya tanggungan, kecuali kalau sudah tidak utang itungannya. Iya harus melunasi utang utangnya (jika ingin berhenti bekerja)."}

Tak hanya itu, hal serupa juga diungkapan oleh informan lainnya, ZA (40 tahun), menjelaskan bahwa pinjaman uang dilakukan oleh masyarakat di Pantai Sendang Biru tanpa menggunakan agunan, namun demikian mereka hanya diharuskan untuk tetap terikat hubungan kerja dengan pemberi pinjaman hingga hutang tersebut lunas. Dengan demikian, adanya hutang - piutang tersebutlah yang menyebabkan ikatan hubungan kerja antar pelaku usaha di Pantai Sendang Biru bertahan dalam jangka waktu yang lama yang masih berjalan sampai saat ini.

\section{"(Hutang) ke juragan mas yang punya perahu. Ga ada (agunan), pokoknya ikut kerja, jadi kalau mau pindah perahu lain harus ngelunasin utangnya semua."}

Sehingga dari pola hubungan kerjasama yang terbentuk tersebut, memunculkan kontrak dengan kepercayaan yang tinggi di antara pelaku usaha perikanan. Artinya, bahwa dengan adanya kemudahan melakukan hutang dan sekaligus pemasaran hasil tangkap ikan maka memunculkan ikatan kontrak sesuai dengan hak dan kewajiban antar pelaku, sehingga kepercayaan itu muncul 
sebagai bentuk loyalitas akan kemudahan tersebut. Siswanto (2005) mendefinisikan loyalitas sebagai satu tekad dan kesanggupan menaati, melaksanakan, dan mengamalkan sesuatu yang ditaati dengan penuh kesadaran dan tanggung jawab. Tekad dan kesanggupan tersebut harus dibuktikan dengan sikap dan perilaku agent yang yang bersangkutan dalam kegiatan sehari-hari untuk melaksanakan pekerjaan yang diberikan dari principal ke agent.

Sehingga secara otomatis dengan adanya loyalitas akan memuncul kepercayaan antar pelaku. Yousafzai, Pallister \& Foxall (2003), mendefinisikan bahwa kepercayaan merupakan pondasi dari suatu hubungan antara dua pihak atau lebih akan terjadi apabila masing-masing saling mempercayai. Kepercayaan ini tidak begitu saja dapat diakui oleh pihak lain, melainkan harus dibangun mulai dari awal dan dapat dibuktikan. Kepercayaan telah dipertimbangkan sebagai katalis dalam berbagai transaksi sesuai dengan yang diharapkan.

Hasil penelitian ini juga sejalan dengan penelitian yang dilakukan oleh Masyhuri (2014) pada perikanan tangkap kasus Muncar dan Bitung bahwa nelayan nelayan harus menjual ikan hasil tangkapan mereka kepada dan dengan harga yang ditentukan oleh "Bos" (pengambek). Selain itu, "Bos" (pengambek) dapat tetap mengikat nelayan untuk menjual ikan kepadanya. Dan hal ini dibuktikan dengan eksistensi pola tersebut berjalan sampai sekarang.

\section{Pola Hubungan Principal - Agent dalam Industri Perikanan Perikanan Tangkap}

Teori keagenan menganalisis hubungan kontraktual antara dua atau lebih individu, kelompok atau organisasi. Salah satu pihak, yakni principal, membuat kontrak baik secara implisit maupun eksplisit dengan pihak lain, yakni agent. Dengan kontrak tersebut diharapkan agent akan melakukan pekerjaan seperti yang diinginkan oleh principal (Jensen and Meckling, 1976 dalam Yustika ). Principal - agent theory memiliki akar masalah pada conflict of interest antar aktor. Dalam hal ini prinsipal adalah aktor yang memiliki kepentingan dan memberikan tugas kepada agen untuk menjalankan kepentingan tersebut.

Berdasarkan teori principal - agent, pengambek merupakan principal, sedangkan juragan kapal (nelayan) ialah agent. Dalam industry perikanan hal tersebut biasa terjadi tetapi dengan nama yang berbeda beda seperti patron client, tetapi pada hakikatnya karakteristik dari aktifitas yang dilakukan oleh masyarakat pesisir sama (Dahuri, Rais, Ginting \& Sitepu, 2001). Berkaitan dengan peran pengambek dan nelayan, salah seorang informan, NHS (50 tahun) yang berprofesi sebagai pengambek menyebutkan bahwa juragan kapal membeli sendiri perahunya, namun untuk modal biaya yang digunakan melaut tersebut berasal dari pengambek sesuai dengan penuturannya di bawah ini.

“...kan ada, ada pengurusnya sekarang.

Tiap kapal ada pengurusnya (pengambek).

Jadi sudah ada catatannya setiap hari mbak. Sistemnya itu kalo tanggungjawab penuh masalah apa itu, biaya-biaya apa saja sana yang menuhin, nanti kalo sudah dapat hasil dikasih."

Lebih lanjut, berkaitan dengan hal ini, posisi principal - agent di Pantai Sendang Biru bergantung pada hubungan tiap-tiap kelompok yang diturunkan menjadi hak dan kewajiban yang harus dipenuhi oleh masing - masing pihak.

\section{Hak dan Kewajiban Nelayan kepada Pengambek}

Sejalan dengan pembahasan sebelumnya bahwa industri perikanan tangkap di Pantai Sendang Biru terdapat hubungan kerja antara Pengambek/ Pengurus Kapal dengan Juragan Kapal. Hubungan tersebut adalah kontrak non-formal yang diikat oleh hutang. Ketika kontrak telah disepakati melalui hutang yang diberikan pengambek kepada nelayan, selanjutnya nelayan berkewajiban untuk menyerahkan seluruh hasil tangkapan kepada pengambek. Alih - alih dapat memasarkan ikan secara lansung kepada pedagang, nelayan hanya berperan untuk mencari ikan dan mendaratkannya ke TPI.

Hal tersebut memberikan konsekuensi bahwa kontrak yang dibangun antar pengambek dan nelayan sangat lemah dan menguntungkan bagi pengambek selaku principal. Menurut Bengen (2001) nelayan tidak memiliki posisi tawar yang baik dalam kegiatan usahanya karena struktur kekuasaan tertinggi berada di tangan pengambek. Disisi lain, nelayan tidak memiliki pilihan lain karena pendapatan yang tidak menentu sehingga sulit untuk mendapatkan akses pembiayaan formal (Masyhuri, 2014).

Disamping kewajiban yang harus dipenuhi oleh nelayan kepada pengambek, nelayan memiliki 
kemudahan dalam mendapatkan pinjaman tidak hanya dalam kegiatan usaha tetapi juga untuk kebutuhan sehari - hari. Jumlah hasil tangkapan yang tidak menentu dan perolehan hasil penjualan ikan yang cukup lama membuat nelayan sering kekurangan biaya untuk kebutuhan sehari - hari. Kemudahan ini yang membuat kontrak antara nelayan dan pengambek berfungsi sebagai dukungan modal yang diharapkan mempertahankan pola kerjasama dalam waktu lama (Muhartono \& Nurlaili, 2018).

Hak dan Kewajiban Pengambek kepada Nelayan

Pengambek/pengurus kapal berkewajiban tidak hanya memberikan bantukan modal tetapi juga memenuhi semua kebutuhan nelayan terkait keperluan sarana produksi. Hal ini sejalan dengan ungkapan salah satu pengambek berikut ini.

"Terkadang nelayan itu punya uang 50

jt. Kapal itu harganya 250, itu yang 200 saya itu, dia yang penting dia kerja. Terus bagiannya dia, dapetnya kapal itu, misalnya bulan ini dalam 50 juta, itu mungkin yang dicicilkan untuk bayar 25 yang 25 milik mereka. Jadi nyicil dari pendapatan. Kalau dapetnya cuma sedikit - sedikit nggak nyicil sama sekali."

Berdasarkan kutipan diatas, sebagai pengambek, ia memberikan pinjaman kepada nelayan (pemilik kapal) untuk membeli kapal maupun untuk modal melaut sesuai kebutuhan nelayan. la menjelaskan bahwa baginya tidak ada masalah seberapa besar pinjaman yang diajukan oleh pemilik kapal selama para pemilik kapal tersebut bersedia untuk bekerjasama. Kerjasama di antara keduanya merupakan hal yang penting bagi pengambek karena melalui hasil melaut yang dilelang dipasar ikan tersebut yang akan digunakan untuk melunasi hutang pemilik kapal kepada pengambek. Sisi positif hubungan kerjasama tersebut merupakan solusi dalam usaha perikanan baik dalam hal permodalan usaha maupun pemasaran ikan hasil tangkapan nelayan (Muhartono \& Nurlaili, 2018).

Di luar ikatan hutang yang mereka miliki, dalam kegiatan operasional bisnis pengambek kan menerima bagi hasil yang dipotong dari penjualan ikan. Besar atau kecilnya prosentase potongan yang dibebankan kepada juragan kapal tergantung pada besarnya jumlah pinjaman yang dimiliki juragan kapal kepada pengambek. Semakin besar jumlah pinjaman juragan kapal kepada pengambek, maka potongan hasil melaut yang akan diberikan juragan kapal kepada pengambek semakin besar. Sehingga nilai bagi hasil yang diberikan kepada pengambek bisa berubah berdasarkan besar atau kecilnya hasil tangkapan. Berikut ini merupakan kutipan penjelasan salah seorang informan yang merupakan pemilik kapal di Pantai Sendnag Biru:

"Ya kan tergantung besarnya persenan untuk pengepul ke tiap kapal itu bedabeda, ada yang ambil 10\%, 3\% bahkan $15 \%$ kebutuhannya, kalo pinjaman sedikit ya persenannya sedikit'

\section{Asimetris Informasi dalam hubungan Pengambek dan Juragan Kapal}

Secara teoretis, North (1990) menyampaikan bahwa akar masalah yang menyebabkan perlu adanya kontrak adalah kondisi assymetric information. Kondisi ini membuat aktivitas bersama yang dilakukan oleh individu tidak dalam kondisi yang setara dimana satu individu memiliki informasi yang lebih banyak daripada individu lainnya sehingga memunculkan pihak yang diuntungkan dan dirugikan.-Dalam hubungan ini, diharapkan terjadinya pendelegasian tugas dari principal kepada agent. Akan tetapi, perbedaan kepentingan sering menjadi penyebab terjadinya asimetri informasi.

Sebagaimana dikatakan Scott (1972) bahwa asimetris informasi merupakan ketidakseimbangan informasi antara pihak yang dapat memperoleh dan memanfaatkan informasi untuk kepentingannya dengan pihak lain yang tidak dapat memperoleh informasi yang sama. Asimetris informasi dapat terjadi sebagai akibat dari pemisahan antara fungsi kepemilikan dan pengelolaan. Hal tersebut sesuai dengan hasil penelitian yang menunjukkan bahwa adanya pemisahan kepemilikan kapal dan pengelolaan kapal selama proses melaut hingga lelang tersebut menyebabkan munculnya asimetris informasi di antara pemilik kapal dan pengambek.

Selanjutnya dikatakan oleh Fozzard (2001), asimetris informasi inilah yang selanjutnya berpotensi menimbulkan masalah keagenan. Penjelasan tersebut sesuai dengan hubungan yang terjadi antara pengambek dan pengurus kapal. Hasil penelitian menunjukkan bahwa para pemilik kapal tidak mengetahui secara pasti terkait harga dan jumlah pendapatan yang seharusnya diterima oleh 
pemilik kapal. Para pemilik kapal mempercayakan dan menyerahkan sepenuhnya pemenuhan kebutuhan kapal selama melaut hingga pembagian hasil lelang ikan di pasar kepada pengambek. Berikut ini merupakan kutipan penjelasan salah satu pemilik kapal di Pantai Sendang Biru:

"Saya masalah harga masalah
pendapatannya berapa kwintal itu saya
nggak pernah ngecek nggak pernah tau,
apa kata mas budi. Apa katanya mas
budi itu, nanti kalau sudah totalan itu baru
dikasih notanya . ini pendapatannya segini,
sigini, segini."

Menurut Scott (1972), terdapat dua jenis asimetris informasi, yaitu adverse selection dan moral hazard. Adverse selection merupakan keadaan di mana principal serta orang-orang dalam lainnya biasanya mempunyai lebih banyak informasi tentang kondisi kekinian dan prospek ke depan dibandingkan dengan agent. Informasi yang seharusnya akan memengaruhi keputusan principal, tidak disampaikan kepada agent sehingga keputusan yang diambil principal tersebut bisa jadi tidak sesuai dengan kondisi faktual organisasi. Sehingga kondisi tersebut dapat memunculkan moral hazard yang merupakan kegiatan diluar pengetahuan agent yang melanggar kontrak yang sebenarnya secara etika atau norma mungkin tidak layak dilakukan. Moral hazard dapat terjadi karena adanya pemisahan pemilikan dengan pengendalian yang merupakan karakteristik kebanyakan perusahaan besar.

Salah seorang pemilik kapal lainnya di Pantai Sendang Biru menjelaskan bahwa adanya ketimpangan informasi yang dimiliki antara pemilik kapal dan pengambek tersebut menyebabkan nelayan (pemilik kapal) tidak mengetahui banyak hal terkait biaya dan proses melaut hingga pelelangan ikan di pasar. Para nelayan mempercayakan seluruhnya kepada pengambek dan hanya menerima pembagian hasil akhir setelah hasil tangkapan ikan tersebut dilelang dan dipotong dengan berbagai biaya selama proses melaut.

"Nelayan taunya cuman ikan dateng di lelang terus dibeli pengepul, harga di pelelangan yang diterima nelayan 15 ribul kilo misalnya sudah dipotongan persenan pengepul (pengambek) sama biaya transaksi jadi harga di pasar bisa 17 ribul kilo. Tapi kadang pengepul (pengambek) dapet pesenan juga dari luar kota."

\section{Hubungan Kontrak yang Melemahkan antara Pengambek dan Pemilik Kapal}

Kállay (2012) menyebutkan bahwa masalah yang menyebabkan perlu adanya kontrak antara lain adalah kondisi ketersediaan informasi, bounded rationality, opportunism, dan asset specificity. Kesediaan informasi merupakan pengetahuan yang dimiliki tiap individu dalam menjalankan kegiatannya. Sedangkan bounded rationality, opportunism, dan asset specificity adalah aspek yang menyebabkan kontrak dapat berjalan tidak sesuai dengan rencana. Firth (1946) kontrak dalam kondisi assymetric information muncul sebagai mekanisme penegakan untuk mempertahankan posisi antar aktor agar tidak ada penyimpangan dari kesepakatan awal. Artinya kontrak dapat mengurangi assymetric information kemudian mengurangi biaya transaksi yang ada dalam sebuah kegiatan.

Namun demikian teori tersebut berseberangan dengan temuan lapangan. Dimana hubungan kontrak yang dibangun antara pengambek dan pemilik kapal dapat melemahkan hubungan salah satu di antara keduanya. Hubungan kontrak antara pemilik kapal dan pengambek lebih menguntungkan bagi pengambek. Hal tersebut dikarenakan semua proses usaha perikanan tangkap ini mulai dari penyedian modal, saprodi dan penjualan ikan dilakukan oleh pengambek. Sehingga secara struktur kekuasaan, pengambek memiliki kekuasaan tertinggi untuk mendapatkan keuntungan. Disisi lain, pemilik kapal merasa tidak dirugikan dengan kondisi tersebut, dikarenakan pengambek menyediakan semua kebutuhan sehari-hari dan kebutuhan melaut bagi pemilik kapal (Manzilati, Efani \& Kornitasari, 2018)

Sejalan dengan penelitian Qurrata (2018) bahwa permasalahan tersebut ditambah dengan kenyataan bahwa pada usaha perikanan laut, posisi tawar (bargaining posisition) yang dimiliki oleh nelayan kecil dan buruh nelayan sangat lemah, baik secara ekonomi maupun politik karena dihadapkan dengan kondisi yang tidak kondusif pada struktur pasar di perikanan laut. Lemahnya posisi daya tawar pemilik kapal tersebut akibat adanya keterikatan hutang yang dimiliki oleh pemilik kapal terhadap pengambek. Pengambek secara langsung akan mengurus kegiatan melaut hingga penjualan hasil tangkapan ikan atas kapal yang telah dibiayainya. Berikut ini merupakan kutipan hasil wawancara salah satu pemilik kapal di Pantai Sendang Biru: 
"Saya masuke ikan ya di pak budi itu. Yang ngambil ikannya kan pak budi, yang modalin pak budi, ya diambil orang lain gak boleh yang modalin dia."

Pemilik kapal juga menjelaskan bahwa meskipun tidak ada agunan yang disyaratkan dalam hutang tersebut, namun jaminan kapal dan ikatan kontrak kerja di antara keduanya menjadi jaminan dalam hutang tersebut. Informan tersebut juga menjelaskan bahwa untuk pengembalian hutang, pihaknya akan memberikan potongan dari hasil lelang ikan tersebut antara 5 - 10\% sesuai dengan besarnya hutang pemilik kapal. Berikut ini merupakan kutipan penjelasan dari salah satu pengambek di Pantai Sendang Biru:

\section{"Pengambek sama yang punya perahu itu ada perjanjiannya. Ya kadang - kadang itu kan lihatnya dari utang piutang itu. Kalau pengambek itu kan kesepakatannya dari ini, dari ee misalkan ini kan perahunya. Nanti misalkan sudah buanyak hutangnya apa bagaimana, apa nutut apa nggak nanti. Hutangnya itu berapa perahunya itu diikutkan berapa itu nanti ada itungannya. Jadi ya buat jaminan lah. Saya ambil ya anu $10 \%$, lihat dari anu, lihat dari hutangnya. Ada yang $5 \%$, ya dilihat dari sangkutan lah. Kalo sampek 50 keatas ya $10 \%$, kalo sampek 50 kebawah ya $5 \%$."}

\section{Kontrak Antara Pemilik Kapal dan Anak Buah Kapal (ABK)}

Pemilik kapal dalam menjalankan kegiatan operasionalnya mencari ikan di lautmemperkerjakan beberapa orang yang biasa disebut dengan Anak Buah Kapal (ABK). Dalam ABK tersebut terdapat nahkoda yang akan menjalankan kapal dan juga beberapa orang lainnya yang bertugas menangkapikan di laut. ABK dalam satu perahu kecil memerlukan $2-5$ orang ABK. Adapun proses pencarian tenaga $A B K$ oleh pemilik kapal melalui informasi dari kerabat atau warga sekitar pemilik kapal. Bagi masyarakat yang bersedia menajdi ABK, mereka secara langsung mengajukan dirinya untuk menjadi $A B K$ pada pemilik kapal. Berikut ini merupakan kutipan penjelasan salah seorang pemilik kapal di Pantai Sendang Biru terkait perekrutan tenaga $A B K$ :

\footnotetext{
"Ya, ya langsung orangnya, orangnya kesini cari kerja gitu yaa, mau ikut gitu ya, jadi yaaa pokoknya mampu nggak mabok gitu dilaut gapapa."
}

Lebih lanjut, berkaitan dengan tugas yang harus dilakukan ABK ketika melaut, informan menjelaskan bahwa selama kegiatan melaut berlangsung tidak ada pembagian kerja tertentu antar ABK dalamkapal. la menjelaskan bahwa pembagian tugas sama rata sesuai dengan perjanjian awal mereka bekerja. Informan tersebut menjelaskan bahwa tugas ABK adalah menjaring ikan dan membersihkan kapal. Para ABK bekerja dari pukul 6 pagi hingga pukul 5 sore, dan diberi jam istirahat pada pukul 12 siang.

"Nggak ada pembagian kerja tertentu, selama sehari kerja full aja rata, pembagian kerja $A B K$ dibagi rata sesuai jobdesk di awal perjanjian, yang menjaring, yang membersihkan kapal yang penting kerja dari jam 6-12 siang nanti istirahat terus lanjut sampek jam 5 sore."

Berkaitan dengan pembagian upah hasil melaut, informan menjelaskan bahwa pembagian upah tersebut dibagi menjadi $1 / 3$ bagian dari masing-masing yang terlibat di dalamnya. Dari $3 / 3$ hasil yang didapat oleh nelayan, 1/3 diberikan kepada ABK (2-5 orang), 1/3 diberikan kepada pemilikkapal, dan 1/3 diberikan kepada pengurus kapal/pengambek. Berbeda dengan perahu kecil, informan menjelaskan bahwa pembagian hasil melaut pada kapal besar pembagian upahnya ialah 50\% untuk pemilik kapal, $10 \%$ untuk biaya perawatan kapal, 20\% untuk pengambek, dan $20 \%$ sisanya diberikan untuk $A B K$ dibagi dengan jumlah ABK per kapal.

"Kalo perahu kecil punya pribadi itu kalo ada yang ikut melaut misal 2-5 orang pembagiannya $1 / 3$ bagian jadi $A B K \quad 1$ bagian, juragan laut 1 bagian, biaya perahu 1 bagian. Maksudnya 1/3 bagian dari hasil melaut jadi ya jumlah ikan/kilo di kali harga per kilonya. Kalo kapal dibagi 2 dulu jadi $50 \%$ untuk juragan darat ya pemilik kapal, 10\% untuk biaya perawatan kapal, 20\% untuk pengambek 20\% ABK dibagi jumlah ABK nya perkapal."

Bahkan, informan lain yang merupakan pengambek sekaligus pedagang besar ikan di Pantai Sendang Biru menjelaskan bahwa hasil tangkapan ikan dalam satu kapal akan diambil terlebih dahulu oleh pengurus kapal/pengambek, selanjutnya akan dibagikan kepada pemilik kapal dan ABK. Jumlah besaran potongan untuk pengambek bergantung pada ikatan (jumlah hutang) pemilik kapal, yakni antara $5-15 \%$. Sisanya tersebut dibagikan $50 \%$ untuk pemilik kapal dan 50\% untuk ABK. 
Dari prosentase upah yang diterima oleh ABK tersebut selanjutnya di mana dibagi lagi sejumlah ABK yang ada dan nahkoda/juru mudi mendapatkan bagian dua kali lipat besar daripada yang diterimaoleh per orang ABK. Berikut ini merupakan kutipan penjelasan salah satu informan yang merupakan pengambek sekaligus pedagang besar ikan di Pantai Sendang Biru:

"Ya ngikuti umumnya disini. Kalo sekoci, satu kapal diambil prosentase pengurus, habis begitu tergantung. Tergantung ikatannya banyak 10\% sampek $15 \%$ dari penghasilan. Kalau ikatannya sedikit dikurangi 5\%. Habis itu dibagi, diambil biaya operasonal. Sisanya itu baru dibagi 2, separo yang punya kapal. Sisanya yang separo untuk $A B K$. ABK ya tergantung jumlahnya. Kalo jumlahnya 4 ya dibagi 5, soalnya juru mudi dua bagian."

Lebih lanjut, salah seorang informan yang merupakan ABK menyebutkan bahwa rata-rata pendapatan yang ia terima dalam sekali melaut terkadang 2 - 3 juta rupiah. Namun demikian, ia kembali menjelaskan bahwa pendapatan yang ia terima sebagai $A B K$ sepenuhnya bergantung pada banyak atau sedikitnya jumlah ikan yang berhasil diperoleh selama melaut.

"Kalau itu saya g pernah tau soal itu. Kadang iya 2jta-3jta ya gitu aja cuman lihat ikan doank kalau ikan banyak ya banyak."

Namun, berdasarkan informasi dari salah seorang ABK menjelaskan bahwa ketika nelayan tidak berhasil mendapatkan ikan selama melaut, maka para ABK dibebankan untuk mengganti biaya solar yang telah dikeluarkan selama melaut.

"iya kalau potongan misal gak dapat ikan itu dipotong solar"

Selanjutnya, berkaitan dengan kerusakan kapal, beberapa informan menyebutkan bahwa kerusakan kapal akan menjadi tanggungjawab pemilik kapal. Namun beberapa informan lain menyatakan bahwa kerusakan kapal menjadi tanggungjawab bersama antara $\mathrm{ABK}$ dan pemilik kapal. Agus, pemilik kapal di Pantai Sendang Biru menjelaskan bahwa pengecekan kapal selalu dilakukan oleh juragan laut (pengambek) sebelum melaut untuk meminimalisasi terjadinya kerusakan kapal di tengah perjalanan melaut.

"Kalo jadi Abk yang mnegerti perahu ya juragan laut, pengecekan tidak bisa ABK dahulu takut disalahkan. Sebelum melaut ada laporan dulu administrasinya lah dicek juga perahunya, tanggal berangat-pulang nama nahkoda tau juragan laut, nama pemilik kapal“"

Lain halnya dengan Agus, menurut salah satu informan yang merupakan ABK menjelaskan bahwa tanggungjawab kerusakan kapal ada di tangan pemilik kapal. Tak hanya itu, pendapat berbeda juga diungkapkan oleh Zaenul, salah seorang ABK lainnya di Pantai Sendang Biru. la menjelaskan bahwa kerusakan kapal akan menjadi tanggungjawab semua $A B K$ yang ada di kapal tersebut, di mana tanggunjawab tersebut harus dibayar oleh ABK dengan dibebankannya potongan biaya kerusakan kapal terhadap upah para $\mathrm{ABK}$.

"Ditanggung semua abk mas la itu kan ada potongan sedikit tadi."

\section{Hubungan Kontrak yang Melemahkan antara Pengambek dan Pemilik Kapal}

Kállay (2012) menyebutkan bahwa masalah yang menyebabkan perlu adanya kontrak antara lain adalah kondisi ketersediaan informasi, bounded rationality, opportunism, dan asset specificity. Kesediaan informasi merupakan pengetahuan yang dimiliki tiap individu dalam menjalankan kegiatannya. Sedangkan bounded rationality, opportunism, dan asset specificity adalah aspek yang menyebabkan kontrak dapat berjalan tidak sesuai dengan rencana.

Kontrak dalam kondisi assymetric information muncul sebagai mekanisme penegakan untuk mempertahankan posisi antar aktor agar tidak ada penyimpangan dari kesepakatan awal. Artinya kontrak dapat mengurangi assymetric information kemudian mengurangi biaya transaksi yang ada dalam sebuah kegiatan (Hargrave \& Andrew, 2004).

Namun demikian, teori tersebut berseberangan dengan temuan lapangan. Hubungan kontrak yang dibangun antara pengambek dan pemilik kapal dapat melemahkan hubungan salah satu di antara keduanya. Hubungan kontrak antara pemilik kapal dan pengambek lebih menguntungkan bagi pengambek. Tidak hanya memiiki kekuasaan lebih tinggi dibandingkan dengan nelayan tetapi juga sebagai pemasok perbekalan untuk melaut.Dimana harga diberikan oleh pengambek kepada nelayan lebih tinggi dari harga pasar. Hal ini sejalan dengan pernyataan salah satu nelayan. 
"Enaknya kalau dari pengambek itu bisa hutang. Tapi ya gitu, harganya beda sama di toko. Misal beras di toko harga sepuluh kita dapenya tiga belas."

Lemahnya posisi daya tawar pemilik kapal tersebut akibat kurangnya sumber modal untuk kegiatan operasional, sehingga pengambek secara langsung akan mengurus kebutuhan kegiatan melaut, bahkan penjualan hasil tangkapan ikan dari nelayan. Dengan demikian dapat dikatakan bahwa pengambek memonopoli sumber daya berdasarkan kekuasaan yang dimiliki. Sejalan dengan Sumarsono, S. (2009) bahwa tenaga kerja dengan dominasi modal cenderung akan melakukan kekuasaan terkait dengan sumber daya yang dimiliki.

\section{Kontrak Antara Pemilik Kapal dan Anak Buah Kapal (ABK)}

Pemilik kapal dalam menjalankan kegiatan operasionalnya mencari ikan di lautmemperkerjakan beberapa orang yang biasa disebut dengan Anak Buah Kapal (ABK). Dalam ABK tersebut terdapat nahkoda yang akan menjalankan kapal dan juga beberapa orang lainnya yang bertugas menangkapikan di laut. Jumlah $A B K$ dalam satu perahu kecil memerlukan $2-5$ orang ABK. Adapun proses pencarian tenaga $\mathrm{ABK}$ oleh pemilik kapal melalui informasi dari kerabat atau warga sekitar pemilik kapal. Bagi masyarakat yang bersedia menajdi ABK, mereka secara langsung mengajukan dirinya untuk menjadi ABK pada pemilik kapal. Berikut ini merupakan kutipan penjelasan salah seorang pemilik kapal di Pantai Sendang Biru terkait perekrutan tenaga ABK:

\section{"Ya, ya langsung orangnya, orangnya kesini cari kerja gitu yaa, mau ikut gitu ya, jadi yaaa pokoknya mampu nggak mabok gitu dilaut gapapa."}

Lebih lanjut, berkaitan dengan tugas yang harus dilakukan $\mathrm{ABK}$ ketika melaut, informan menjelaskan bahwa selama kegiatan melaut berlangsung tidak ada pembagian kerja tertentu antar ABK dalam kapal. la menjelaskan bahwa pembagian tugas sama rata sesuai dengan perjanjian awal mereka bekerja. Informan tersebut menjelaskan bahwa tugas $\mathrm{ABK}$ adalah menjaring ikan dan membersihkan kapal. Para ABK bekerja dari pukul 6 pagi hingga pukul 5 sore, dan diberi jam istirahat pada pukul 12 siang.

"Nggak ada pembagian kerja tertentu, selama sehari kerja full aja rata, pembagian kerja $A B K$ dibagi rata sesuai jobdesk di awal perjanjian, yang menjaring, yang membersihkan kapal yang penting kerja dari jam 6-12 siang nanti istirahat terus lanjut sampek jam 5 sore."

Berkaitan dengan pembagian upah hasil melaut, informan menjelaskan bahwa pembagian upah tersebut dibagi menjadi $1 / 3$ bagian dari masing-masing yang terlibat di dalamnya. Dari 3/3 hasil yang didapat oleh nelayan, 1/3 diberikan kepada ABK (2-5 orang), 1/3 diberikan kepada pemilikkapal, dan 1/3 diberikan kepada pengurus kapal/pengambek. Berbeda dengan perahu kecil, informan menjelaskan bahwa pembagian hasil melaut pada kapal besar pembagian upahnya ialah 50\% untuk pemilik kapal, 10\% untuk biaya perawatan kapal, 20\% untuk pengambek, dan 20\% sisanya diberikan untuk ABK dibagi dengan jumlah ABK per kapal.

"Kalo perahu kecil punya pribadi itu kalo ada yang ikut melaut misal 2-5 orang pembagiannya $1 / 3$ bagian jadi $A B K \quad 1$ bagian, juragan laut 1 bagian, biaya perahu 1 bagian. Maksudnya 1/3 bagian dari hasil melaut jadi ya jumlah ikan/kilo di kali harga per kilonya. Kalo kapal dibagi 2 dulu jadi $50 \%$ untuk juragan darat ya pemilik kapal, 10\% untuk biaya perawatan kapal, 20\% untuk pengambek $20 \%$ ABK dibagi jumlah ABK nya perkapal."

Bahkan, informan lain yang meru pakan pengambek sekaligus pedagang besar ikan di Pantai Sendang Biru menjelaskan bahwa hasil tangkapan ikan dalam satu kapal akan diambil terlebih dahulu oleh pengurus kapal/ pengambek, selanjutnya akan dibagikan kepada pemilik kapal dan ABK. Jumlah besaran potongan untuk pengambek bergantung pada ikatan (jumlah hutang) pemilik kapal, yakni antara $5-15 \%$. Sisanya tersebut dibagikan $50 \%$ untuk pemilik kapal dan 50\% untuk ABK. Dari prosentase upah yang diterima oleh $A B K$ tersebut selanjutnya di mana dibagi lagi sejumlah $A B K$ yang ada dan nahkoda/juru mudi mendapatkan bagian dua kali lipat besar daripada yang diterima oleh per orang ABK. Berikut ini merupakan kutipan penjelasan salah satu informan yang merupakan pengambek sekaligus pedagang besar ikan diPantai Sendang Biru:

"Ya ngikuti umumnya disini. Kalo sekoci, satu kapal diambil prosentase pengurus, habis begitu tergantung. Tergantung 
ikatannya banyak $10 \%$ sampek $15 \%$ dari penghasilan. Kalau ikatannya sedikit dikurangi 5\%. Habis itu dibagi, diambil biaya operasonal. Sisanya itu baru dibagi 2, separo yang punya kapal. Sisanya yang separo untuk $A B K$. ABK ya tergantung jumlahnya. Kalo jumlahnya 4 ya dibagi 5 , soalnya juru mudi dua bagian."

Lebih lanjut, salah seorang informan yang merupakan $A B K$ menyebutkan bahwa rata-rata pendapatan yang ia terima dalam sekali melaut terkadang $2-3$ juta rupiah. Namun demikian, ia kembali menjelaskan bahwa pendapatan yang ia terima sebagai ABK sepenuhnya bergantung pada banyak atau sedikitnya jumlah ikan yang berhasil diperoleh selama melaut. Hal ini, mengartikan bahwa produktifitas nelayan dilihat dari banyak sedikit ikan hasil tangkapan sehingga semakin produktif maka akan mendapatkan upah yang lebih besar. Sejalan dengan Jimad (2012) dalam system pengupahan yang menggunakan hitungan berdasarkan produktifitas yang dihasilkan sesuai dengan kontrak dapat dikatakan bahwa system pengupahan yang berlaku adalah bagi hasil. Hal tersebut bertentangan dengan Setiadi (2009) bahwa tingginya tingkat upah yang tinggi tidak menjamin tingginya produktivitas kerja, tetapi hal tersebut disebabkan faktor-faktor lain di luar upah dan jaminan social. Dan hal tersebut berbeda dengan industry yang ada di pesisir Malang Selatan.

"Kalau itu saya g pernah tau soal itu. Kadang iya 2jta-3jta ya gitu aja cuman lihat ikan doank kalau ikan banyak ya banyak."

Namun, berdasarkan informasi dari salah seorang $A B K$ menjelaskan bahwa ketika nelayan tidak berhasil mendapatkan ikan selama melaut, maka para $A B K$ dibebankan untuk mengganti biaya solar yang telah dikeluarkan selama melaut.

"iya kalau potongan misal gak dapat ikan itu dipotong solar"

Selanjutnya, berkaitan dengan kerusakan kapal, beberapa informan menyebutkan bahwa kerusakan kapal akan menjadi tanggungjawab pemilik kapal. Namun beberapa informan lain menyatakan bahwa kerusakan kapal menjadi tanggung jawab bersama antara ABK dan pemilik kapal. Agus, pemilik kapal di Pantai Sendang Biru menjelaskan bahwa pengecekan kapal selalu dilakukan oleh juragan laut (pengambek) sebelum melaut untuk meminimalisasi terjadinya kerusakan kapal di tengah perjalanan melaut.
"Kalo jadi Abk yang mnegerti perahu ya juragan laut, pengecekan tidak bisa $A B K$ dahulu takut disalahkan. Sebelum melaut ada laporan dulu administrasinya lah dicek juga perahunya, tanggal berangat-pulang nama nahkoda tau juragan laut, nama pemilik kapal"

Lain halnya dengan Agus, menurut salah satu informan yang merupakan ABK menjelaskan bahwa tanggungjawab kerusakan kapal ada di tangan pemilik kapal. Tak hanya itu, pendapat berbeda juga diungkapkan oleh Zaenul, salah seorang ABK lainnya di Pantai Sendang Biru. la menjelaskan bahwa kerusakan kapal akan menjadi tanggungjawab semua ABK yang ada di kapal tersebut, di mana tanggunjawab tersebut harus dibayar oleh $\mathrm{ABK}$ dengan dibebankannya potongan biaya kerusakan kapal terhadap upah para ABK.

"Ditanggung semua abk mas la itu kan ada potongan sedikit tadi."

Hal tersebut menunjukan bahwa dalam industry pesisir dalam skema pembagian untung maupun kerugian menggunakan mekanisme bagi hasil sesuai dengan kontrak yang disepakati antar pelaku. Jam, Syed, Tahir \& Farooq, (2010) mendefinisikan bahwa mekanisme kerja dengan menggunakan skema bagi hasil memberikan keuntungan yang adil bagi principal dan agent karena mendapatkan kompensasi untung atau rugi sesuai dengan kontribusinya. Jimad (2012) sistem bagi hasil membuat setiap devisi akan berusaha menghasilkan yang paling banyak yang dapat dicapai, sehingga mempengaruhi jumlah nominal bagi hasil yang diterima karyawan. Sejalan dengan Yahya \& Edy (2010) bahwa mekanisme dalam bagi hasil baik untuk profit maupun loss akan membagi hasil aktifitas ekonomi sesuai dengan kontribusi dan kesepakatan yang antar pelaku ekonomi.

\section{Kontrak antara Pengambek, Nelayan, dan Kuli Logistik}

Setiap pengurus kapal memiliki hubungan dengan pedagang yang menyuplai kebutuhan kapal saat melaut. Supplier ini biasanya memurapak pedagang sembako yang ada di Sendang Biru. Ada juga pengurus kapal yang sekaligus memiliki toko untuk suplai kebutuhan melaut. Pelaksana pemenuhan kebutuhan logsitik tersebut dilakukan oleh kuli bongkar. Kuli bongkar bertugas untuk mendistribusikan logistik yang dikirim dari supplier untuk kapal yang akan berangkat melaut. Hubungan 
kerja kuli bongkar hanya dengan nelayan. Mereka menerima upah setelah nelayan pulang melaut berupa ikan sebanyak $5 \mathrm{~kg} /$ keranjang dengan jumlah sesuai hasil tangkapan yang diperoleh. Jadi kuli bongkar tidak memiliki hubungan kerja dengan pengurus kapal maupun supplier logistik.

Kebutuhan logistik dalam sebuah kapal ditentukan oleh pengambek selaku pengurus kapal. Salah seorang informan menjelaskan bahwa setiap nelayan terdapat pengurus kapal masing-masing. Tugas dari pengurus kapal ialah memenuhi kebutuhan operasional dan logistik nelayan selama melaut. la juga menjelaskan bahwa pengurus kapal (pengambek) akan memberikan potongan sebesar 5\% dari pendapatan kotor hasil melaut sebagai pengganti biaya logsitik yang telah dikeluarkan.

"Semua nelayan ada pengurus masing-
masing, kerjasama nelayan dengan
pengambek misal 1 pengurus membawahi
10 kapal, dst. Mereka memenihi kebutuhan
nelayan selama melaut, baik operasional
maupun logistik ditanggung oleh
pengambek dipotong 5\% dari pendapatan
kotor melautnya."

Berkaitan dengan upah yang diterima oleh kuli bongkar, kuli bongkar hanya bertugas memberikan jasa angkut logistik kepada nelayan untuk kebutuhan melaut, sehingga upah yang diterima oleh kuli bongkar hanya berasal dari jasa angkutnya saja. Salah seorang informan yang merupakan kuli bongkar menjelaskan bahwa pengambek akan memberi informasi kebutuhan logistik yang perlu dikirim ke kapal. Selanjutnya, pengambek yang akan membayar kebutuhan logisktik tersebut. Upah yang diterima oleh kuli bongkar adalah upah atas jasa angkut yang telah diberikannya.

\begin{abstract}
"Istilahnya kan kita kuli angkut gitu. Yang bayar (logistik) pengambek, yang ngasih tau kapal mana butuh logistik berapa ya pengambek. Cuman kita dapet upah dari jasa ngangkut aja."
\end{abstract}

\section{KESIMPULAN DAN REKOMENDASI KEBIJAKAN}

\section{Kesimpulan}

Berdasarkan hasil analisis data dan pembahasan yang telah dilakukan, maka dapat disimpulkan bahwa usaha penangkapan ikan di industri perikanan pesisir Malang Selatan terjalin dengan hubungan kerja/industrial (principal-agent) melalui kontrak pembiayaan informal antara Nelayan dan Pengambek. Sebagaimana kita ketahui bahwa hampir di semua usaha penangkapan ikan di Indonesia mengalami keterbatasan akses pembiayaan formal seperti lembaga keuangan bank sehingga sehingga membuat nelayan tidak ada pilihan pembiayaan lain. Kontrak pembiayaan tersebut memberikan konsekuensi kepada nelayan, dimana nelayan terikat dengan kontrak yang melemahkan posisi tawarnya dalam bisnis perikanan tangkap. Lemahnya bargaining position pemilik kapal tersebut akibat kurangnya sumber modal untuk kegiatan bisnis dan pemenuhan kebutuhan sehari hari, sehingga pengambek memiliki kekuasaan lebih tinggi dibandingkan nelayan sebagai pemilik kapal. Maka dapat dikatakan bahwa hubungan kontrak yang terbentuk di pesisir pantai Sendangbiru membuat pengambek memonopoli sumber daya berdasarkan kekuasaan yang dimiliki. Sehingga kontrak yang terbentuk bisa dikatakan menguntungkan bagi nelayan karena untuk menjaga keberlanjutan usaha perikanan tangkap, akan tetapi kontrak ini secara kelembagaan (principal-agent) dikatakan melemahkan bagi nelayan karena menghilangkan kekuasaan akan pengelolaan hasil tangkapan.Akhirnya, kontrak tersebut seakan akan menguntungkan bagi nelayan akan tetapi sebenarnya melemahkan dalam sebuah kontrak. Hal tersebut dilatarbelakangi adanya kepercayaan nelayan kepada pengambek yang menimbulkan asymmetry information, terutama dalam pemenuhan kebutuhan perbekalan sampai dengan besaran nilai bagi hasil dari hasil tangkapan ikan.

\section{Rekomendasi Kebijakan}

Adapun saran yang diberikan berdasarkan hasil penelitian adalah perlunya membentuk dan membangun lembaga keuangan informal yang ramah bagi nelayan dengan mengoptipmalkan peran modal sosial yang sudah terbentuk dikelompok nelayan, sehingga pelan-pelan akan mengurangi ketergantungan nelayan kepada para pengambek dan akan memberikan kemandirian dan kesejahteraan bagi para nelayan. Salah satunya dengan membentuk Financial Social Sharing, yaitu lembaga keuangan informal yang dikelola oleh para nelayan dengan sistem kekeluargaan dan kepercayaan. 


\section{UCAPAN TERIMA KASIH}

Penulis mengucapkan terima kasiih kepada narasumber, masyarakat Pantai Sendangbiru, serta seluruh pihak yang telah mendukung penyelesaian penelitian ini.

\section{DAFTAR PUSTKA}

Kállay, B. (2012). Contract Theory of the Firm. Economics \& Sociology. Vol. 5(1), 39-50.

Bengen, D.G. (2001). Sinopsis Ekosistem dan Sumber Daya Alam Pesisir dan Lautan. Bogor (ID): Pusat Kajian Sumber Daya Peisisr dan Lautan, Institut Pertanian Bogor.

Blumer, H. (1969). Symbolic Interactionism. Perspective and Method. USA : Prentice-Hall Inc.

Dahuri, R., Rais, J., Ginting, S.P. \& Sitepu, M.J. (2001). Pengelolaan Sumber Daya Wilayah Pesisir dan Lautan Secara Terpadu. Jakarta (ID): PT Pradnya Paramita.

Firth, R. (1946). Malay Fishermen: Their Peasant Economy. London (UK): Butler and Tunner, Ltd.

Hargrave, T.J., \& Andrew H.V.V. (2004). A Collective Action Model of Institutional Innovation. Forthcoming Academy of Management Review November 22, 2004.

Jam, F.A., Syed, T.H., Tahir, M.Q,. \& Farooq, H. (2010). Agency Theory IIslamic Perspective. Interdisciplinary Journal Of Contemporary Research In Business, Vol. 2(4).

Jimad, H. (2012). Perbandingan Kinerja Menejemen Syariah Dengan Manajemen Konvensional (Perspektif Gaji Karyawan). Artikel

Koentjaraningrat. (1990). Sejarah Teori Antropologi. Jakarta (ID): UI Press.

Manzilati, A., Efani, A., \& Kornitasari, Y. (2018). Identifikasi Pembiayaan Sektor Perikanan Melalui Hubungan Principal Agent pada Kontrak Bagi Hasil: Skenario Praktis dan Aplikasi (Studi Kasus Perikanan Pesisir Malang Selatan). Laporan Akhir Penelitian Terapan Unggulan Perguruan Tinggi. Universitas Brawijaya.

Manzilati, A., Fadjar, N.S., \& Danarti, T. (2010). Islamic Entrepreneurial Character and Local Manner: The Javanese Cultural Entrepreneur. Tangerang (ID): The 2nd Indonesian International Conference on Innovation, Entrepreneurship, and Small Business; Small Business. (IICIES 2010).

Masyhuri, I. (2014). Pembiayaan Nonformal Usaha Perikanan Tangkap: Kasus Muncar dan Bitung. Jurnal Ekonomi dan Pembangunan. Vol. 22(2).
Masyhuri, I. (1999). Pemberdayaan Nelayan Tertinggal Dalam Mengatasi Krisis Ekonomi. Telaah Terhadap Sebuah Pendekatan. Jakarta (ID): Puslitbang Ekonomi dan Pembangunan LIPI

Moleong, L. (2006). Metodologi Penelitian Kualitatif. Bandung(ID): PT. Remaja Rosdakarya.

Muhartono, R. \& Nurlaili. (2018). Hutang sebagai Pengikat Hubungan Nelayan dan 'Pengambe' di Kabupaten Jember, Provinsi Jawa Timur. Jurnal Sosial Ekonomi Kelautan dan Perikanan. Vol. 13 (2).

North, D.C. (1990). Institutions, Institutional Change and Economic Performance. USA: Cambrige University Press.

Satria, A. (2002). Pengantar Sosiologi Masyarakat Pesisir. Jakarta (ID): PT. Pustaka Cidesindo.

Scott, J.C. (1972). Patron Client, Politics and Political Change in South East Asia' dalam Friends, Followers and Factions: A Reader in Political Clientalism, Steffen W. Schmidt, James C. Scott dkk. (eds.). Berkeley: University of California Press.

Setiadi, (2009). Pengaruh Upah Dan Jaminan Sosial Terhadap Produktivitas Kerja Karyawan Di PT Semarang Makmur Semarang. Thesis.

Sugiyono. (2012). Memahami Penelitian Kualitatif. Bandung (ID): ALFABETA.

Sumarsono, S. (2009). Ekonomi Manajemen Sumber Daya Manusia dan Ketenagakerjaan. Yogyakarta (ID): Graha IImu

Qurrata, V.A. (2018). Patron Client: Kontrak Semi Mudharabah Dalam Teori Keagenan Di Perikanan Laut. Artikel.

Yahya, M. \& Edy, Y.A. (2010). Teori Bagi Hasil (Profit And Loss Sharing) Dan Perbankan Syariah Dalam Ekonomi Syariah. Jurnal Dinamika Ekonomi Pembangunan, Vol. 1(1).

Yousafzai, S. Y., Pallister, J. G., \& Foxall, G. R. (2003). A Proposed Model of E- Trust for Electronic Banking. Technovation, 23, 847-860.

Yustika, A.E. (2010). Ekonomi Kelembagaan; Definisi, Teori dan Strategi. Jakarta (ID): Penerbit Erlangga. 